\title{
Performance of CHEERs Based Equilibrium Exchange Rate of Pakistan
}

\author{
Muhammad Awais Bhatti (Corresponding author) \\ School of Business Management, College of Business, University Utara Malaysia, \\ Sintok-Kedah, Malaysia \\ E-mail: awaisbhatti_786@yahoo.com \\ Noman Arshed \\ University of Edinburgh, UK \\ Muhammad Haseeb \\ College of Business, University Utara Malaysia, \\ Sintok-Kedah, Malaysia
}

Received: February 17, 2013 Accepted: March 7, 2013 Published: March 13, 2013

doi:10.5296/bmh.v1i1.3374 URL: http://dx.doi.org/10.5296/bmh.v1i1.3374

\begin{abstract}
In pursuit to sketch the Pakistan USA Exchange Rate patterns for the duration of 1991M3 to 2010M5 using the CHEERS model, the role of Goods Market and Financial Market is implied through the Purchasing Power Parity (PPP) and Uncovered Interest Parity (UIP) respectively. The results using Vector Error Correction Model (VECM) revealed that both Parities work in combination with near unity elasticities to explain the motion of Exchange Rate in Long Run, but it showed very slow degree of convergence (around 3 and half years) to this equilibrium path after any shock.
\end{abstract}

Keywords: exchange rate modeling and forecasting, purchasing power parity, uncovered interest parity 


\section{Introduction}

Actively trading economies in the world, because of their dynamic conditions alter the rate (i.e. Exchange Rate) that makes the price level of that particular economy with its trading economic partners. Hence a stability persuading policy maker will tend to foresee how this rate is behaving and to which economic factors it is being sensitive too.

Especially, for the economy like Pakistan where major exports are agricultural goods and major imports are Crude oil and machinery, as both group or type of commodities whose nature tends to make it price inelastic hence for Pakistan, there is no control on the prices that it receives or pays by altering the quantity it sells or buys, in this condition the fluctuations in the currency value (i.e. rising Exchange Rate) further damage the county's balance of payments. Given historical pattern of the Exchange rate of Pakistan in figure 1, depict a rising trend throughout which kick started from early 80's. Like any other pehnomenon in ecnonomics, Exchnage Rate behavior can also be seen as a result of demand and supply forces, and in this case it is the demand and supply of currency. And market forces or arbitrage opportunity drives the Exchange Rate up or down. Hence the rising Exchange Rate prepresent a constant pressure from the increasing demand of Foreign currency (i.e. US Dollars)

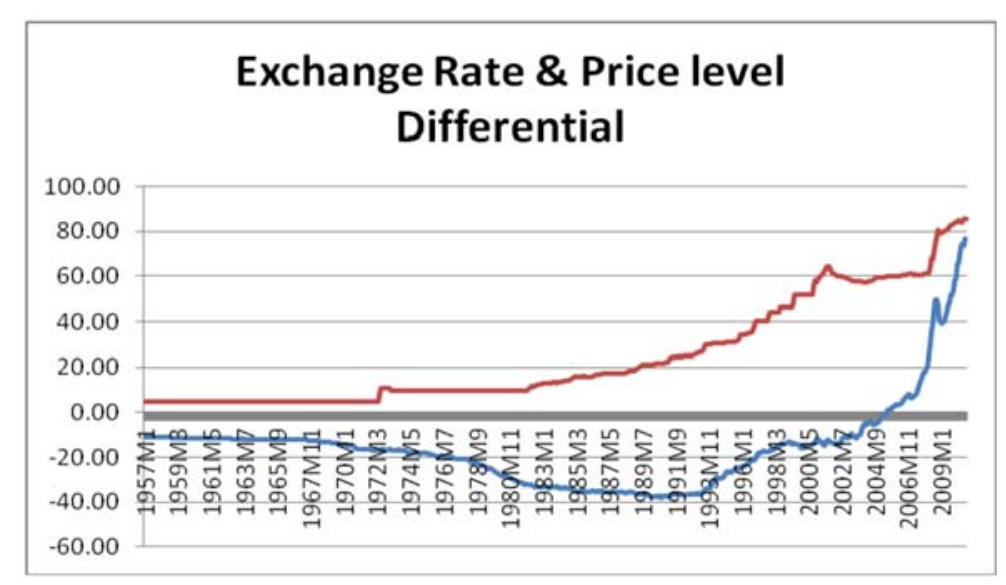

Figure 1. Exchange rate \& price level differential

Analysing the current accout channel from where the goods market is used to interact between Pakistan and USA, the graph of the increasing price level differential from early 80 's justifies the increase in the purchasing power of the consumers to buy relatively cheaper goods from the foreign market. For this reason there will be an increas in the demand of the foriegn currency which drives the Exchnage Rate up. this relationship between the price levels and the Exchange Rate is known as the Purchasing Power Parity, such that if this Parity holds then there will be same prices all over the world converted to same currency units and chnages in the exchange will try to stabalise this equality. In the financial market, investors tends to go towards the country, where there is higher return on the capital, this flow in and 
out of capital stops when the returns in the investment in both countries equate in terms of single currency unit, in other words Exchnage Rate adjusts to remove this arbitrage opportunity. In the graph of Fiancial Market and Exhange Rate, the rise in the interest rate of Pakistan relative to USA are mirrored in the peaks of the change in Exchange Rate. Except for the period of late 90's where Financial market of Pakistan crahsed due to international secutiry conditions. This correspondence between the interest rate and the Exchange Rate is termed as Uncovered Interest Parity.

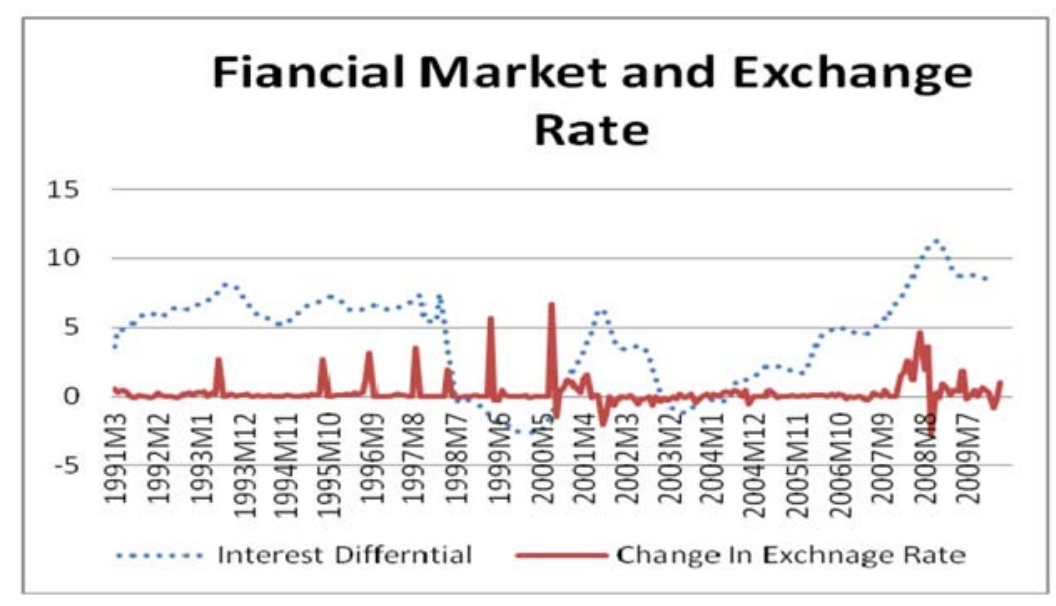

Figure 2. Financial market and exchange rate

The result is that both Goods and Capital Market affects the Exchange Rate, so the Equilibrium Exchange Rate must be responsive to the changes to changes in these markets. The comparison of this Equilibrium Exchange Rate with the actual Exchange Rate will tell how far is the economy from the optimal balancing behavior?, as any imbalance will cause repercussions to any of the Current Account or Capital Account through the Goods or Capital Market respectively.

As importance of Exchange rate is described in the introduction section, this paper will address that issue by trying to fulfill following set of objectives.

1) Statistically and empirically reasonable econometric model that can give insight to how Purchasing Power Parity and Uncovered Interest Parity effects exchange rate.

2) Using in sample and out sample forecasting checking the performance of the Exchange rate model.

This study will be organized in following manner. Firstly, a review of Literature will be presented to show that importance of Exchange Rate and how it was sorted out? Secondly, the historical relationship of the PPP and UIP will be explained using a mathematical and statistical model. Thirdly, a thorough analysis of historical pattern of individual variables will be done to find preliminary connections with each other. Finally, set of data will be used to estimate the stochastic equation put forward in second section and then test the forecasting 
ability of this model. And in this section we will also derive conclusion from the interpretations of the model and its Implications.

\section{Literature Review}

After introducing PPP as a tool for explaining the Exchnage Rate patterns by (Cassel, G. 1918), this Parity became a common use in papers to determine Exchange Rate. Such as Keynes stated what, then, has determined and the will determine the value of Franc? First, the quantity, present and prospective, of the francs in circulation. Second, the amount of purchasing power which it suits to public to hold in that shape. Keynes (Introduction to French edition, 1924, xviii)

In correspondence to application of PPP, (Clostermann \& Schnatz, 2000) implied that if this PPP holds strictly then Exchange Rate should be constant over time and the it will adjust to equate the prices between two counties in one currency terms.

Early papers like (Baillie \& Selover, 1987) and (Enders, 1988) used cointegration method to explan Exchnage Rate patterns using the Price Differential between home and foriengn country (PPP) and found evidence for the presence of PPP only in the Bretton Wood period. (Baillie \& Selover, 1987) carried on to find the equilibriun between Nominal Exchange Rate and Price Differenctial, the results proposed the presence of non-stationary Real Exchange Rate.

This PPP framework beagn with a basic analysis by (Frankel, 1976) who used only the varities of domestic price level indicators to find a significant relationahsip, with the price indices effecting the Exchange Rate with unit elasticity. All of these above papers considered PPP as a foundation for the Exchange Rate modelling and failed to find co-integration, so it urged to expand the model that will be more comprehensive in grasping the dynamics in the Exchange Rate.

(Clostermann \& Schnatz, 2000), (Juselius \& MacDonald, 2004) and (Camarero \& Tamarit, 1996) expanded the model uisng Uncovered Interest Parity to incorporate the goods and capital market interaciton between the two countries. (Juselius \& MacDonald, 2004) used VECM approach in order to find long run and short run relationships among the nominal Exchange Rate, PPP \& UIP and applied restrictions on this CHEERS based final long run equilibrium of USA/Japan Exchange Rate to see the significance of individial Parities, the resutls proved that both Parities were working in combination. The results of (Clostermann \& Schnatz, 2000) showed a slow convergence in the equilibrium of Euro/Dollar Exchange Rate using the PPP and UIP. These stated papers proved that the CHEERS model works well inside the given sample.

While testing outsample perfornance of the model, (Clostermann \& Schnatz, 2000) compares the forecasts of this model with the forecasts of Random Walk model and Moving Average (1) model, the results were opposite to what whould be expected after insample performance, the models was not able to outforecast the RW or MA(1) model.

For the case of Pakistan, (Kemal \& Haider, 2004) tested PPP against several countries USA, 
UK, Euro and Japan. The results showed the against the existence of PPP as the Real Exchange Rate came out to be non-stationary. As per UIP, (Kemal \& Haider, 2004) found correlation among the Nominal Exchange Rate and the nominal Interest Diffential.

(Qayyum, Khan, \& Kair-u-Zaman, 2004) used PPP to estimate the degree of misalignment of Exchange Rate as mentioned a high cost of misalignment in work done in 1990's and 2000's. using Vector Error Correction Model they found out cointegration with unit elasticity in PPP. But the effects of shocks disappear after a long time due to of slow convergence speed. (Qayyum, Khan, \& Kair-u-Zaman, 2004) reasoned trade libralization policies of Pakistan in 1980's for the accpetence of Law of One Price.

Similar work done by (Khan \& Qayyum, 2007) found no mean reversion on the basis of simple stationarity test of Real Exchange Rate but after using the Johanson-Juselius Multivariate Cointegration test, results found convergence in PPP based Exchange Rate model with around $12 \%$ correction per quarter.

(Ahmad, 2005) used SAARC coutrries like Pakistan, India and Bangladesh and looked for the presence of Purchasing Power Parity using several non-regression based tests. And for the data range of 1975Q1 to 1981Q4, (Ahmad, 2005) proved the presence of relative version of the PPP in Pakistan.

Most of the papers that considered the PPP and UIP in the co-integration set are work done by foreign authors and on the other hand, domestic papers did not considered UIP to be incorporated in the estimated relationship so this paper will bring VECM approach and apply the CHEERs based framework on the Exchange Rate of Pakistan/USA and see the performance of the model and the implications that the Equilibrium Exchange Rate brings with it.

Following section will provide insight to the mathematical model that (Ahmad, 2005) and (Juselius \& MacDonald, 2004) and provide the final mathematical relationship between the nominal Exchange Rate, Price Differential and the Interest Differential, that is known as CHEERs model. This paper will estimate the model built from (Juselius \& MacDonald, 2004) which integrates UIP and PPP for the case of Pakistan which was missing in the all the studied which are done for Pakistan.

\section{Theoretical Model}

In this section the empirical relationship will be explained using a mathematical model and at the end the final form will be converted in to stochastic form for the econometric modeling to be applied.

\subsection{Purchasing Power Parity (PPP) Model}

Start with the current account interaction between countries using the Law of One price Equation

$\mathrm{P}_{\mathrm{t}}=\mathrm{S}_{\mathrm{t}} \mathrm{P}_{\mathrm{t}}^{*}---(1)$

Here $\mathrm{P}_{\mathrm{t}}=\mathrm{CPI}$ of Pakistan, $\mathrm{S}_{\mathrm{t}}=$ Nominal Exchange Rate, and $\mathrm{P}_{\mathrm{t}} *=\mathrm{CPI}$ of USA 
Logarithmic representation of equation (1)

$\mathrm{P}_{\mathrm{t}}=\mathrm{S}_{\mathrm{t}}+\mathrm{P}_{\mathrm{t}}^{*}---(3)$

Converting equation (2) it into the stochastic form we get

$\mathrm{S}_{\mathrm{t}}=\alpha_{10}+\beta_{11} \mathrm{P}_{\mathrm{t}}-\beta_{12} \mathrm{P}_{\mathrm{t}}^{*}+\mu_{\mathrm{t}}--$

If the Purchasing Power Parity holds then it is expected to have parameters $\beta_{11}$ and $\beta_{12}$ to be statistically near to unity and for the validity of this model $\mu_{\mathrm{t}} \sim \mathrm{I}(0)$.

\subsection{Interest Parity (UIP) Model}

This Uncovered Interest Parity describes the role of financial market on the exchange rate.

$\Delta \mathrm{S}^{\mathrm{e}}{ }_{\mathrm{t}+1}=\mathrm{i}_{\mathrm{t}} / \mathrm{i}_{\mathrm{t}} *---(5)$

Here $\Delta \mathrm{S}_{\mathrm{t}+1}^{\mathrm{e}}=$ Future Expected change in Nominal Exchange Rate, $\mathrm{i}_{\mathrm{t}}=$ Bond Rate of Pakistan, and $\mathrm{i}_{\mathrm{t}} *=$ Bond Rate of USA.

Taking logs of equation (5) and converting it into stochastic form

$\Delta \mathrm{S}_{\mathrm{t}+1}^{\mathrm{e}}=\alpha_{20}+\beta_{21} \mathrm{i}_{\mathrm{t}}-\beta_{22} \mathrm{i}_{\mathrm{t}}+\mathrm{t}^{\mathrm{t}--}(6)$

Uncovered Interest Parity holds if the parameters $\beta_{21}$ and $\beta_{22}$ must be significant and near to unit. And this model will be valid if ${ }_{t} \sim \mathrm{I}(0)$

\subsection{PPP Model with Capital Account (Relative PPP)}

$\mathrm{S}_{\mathrm{t}}=\mathrm{P}_{\mathrm{t}}-\mathrm{P}_{\mathrm{t}}^{*}---(7)$

Taking first difference of equation (7)

$\Delta \mathrm{S}_{\mathrm{t}}=\Delta \mathrm{P}_{\mathrm{t}}-\Delta \mathrm{P}_{\mathrm{t}}^{*}---(8)$

Form UIP

$\Delta \mathrm{S}_{\mathrm{t}+1}^{\mathrm{e}}=\mathrm{i}_{\mathrm{t}}-\mathrm{i}_{\mathrm{t}}^{*}---(9)$

From fisher relationship

$\mathrm{r}_{\mathrm{t}}=\mathrm{i}_{\mathrm{t}}-\Delta \mathrm{P}_{\mathrm{t}+1}^{\mathrm{e}}---(10)$

$\mathrm{r}_{\mathrm{t}}^{*}=\mathrm{i}_{\mathrm{t}} *-\Delta \mathrm{P}_{\mathrm{t}+1} * \mathrm{e}---(11)$

Here $r_{t}=$ Real Interest Rate of Pakistan, $r_{t}{ }^{*}=$ Real Interest Rate of USA, $\Delta P_{t+1}{ }^{e}=$ Future Expected Inflation in Pakistan, $\Delta \mathrm{P}_{\mathrm{t}+1} *^{\mathrm{e}}=$ Future Expected Inflation in USA

So using equation (10) and (11) in equation (9) to form

$\Delta \mathrm{S}_{\mathrm{t}+1}^{\mathrm{e}}=\left(\mathrm{r}_{\mathrm{t}}-\mathrm{r}_{\mathrm{t}}^{*}\right)+\left(\Delta \mathrm{P}_{\mathrm{t}+1}^{\mathrm{e}}-\Delta \mathrm{P}_{\mathrm{t}+1}{ }^{\mathrm{e}} *\right)$---- (

Assuming that trade equates the real interest rate so equation (12) becomes

$\Delta \mathrm{S}_{\mathrm{t}+1}^{\mathrm{e}}=\Delta \mathrm{P}_{\mathrm{t}+1}^{\mathrm{e}}-\Delta \mathrm{P}_{\mathrm{t}+1}{ }^{\mathrm{e}} *-$ 
$\Delta \mathrm{S}_{\mathrm{t}+1}=\alpha_{30}+\beta_{31} \Delta \mathrm{P}_{\mathrm{t}+1}-\beta_{32} \Delta \mathrm{P}_{\mathrm{t}+1} *+\eta_{\mathrm{t}}---(14)$

$q_{t}=\alpha_{40}+\beta_{41} q_{t-1}+\eta_{t}---(15)$

So for this model to hold both parameters $\beta_{31}$ and $\beta_{32}$ must be significant and $\beta_{31}=-\beta_{32}=1$ and $\eta_{\mathrm{t}} \sim \mathrm{I}(0)$ and this model can also holds in weak form if $\mathrm{q}_{\mathrm{t}}$ is $\mathrm{I}(0)$ such that $\alpha_{40} \neq 0$ and $\beta_{41} \neq 1$

Hence these PPP and UIP model can be estimated jointly as follows

$\mathrm{S}_{\mathrm{t}+1}=\mathrm{P}_{\mathrm{t}}-\mathrm{P}_{\mathrm{t}}^{*}+\mathrm{i}_{\mathrm{t}}-\mathrm{i}_{\mathrm{t}} *+\gamma_{\mathrm{t}}---(16)$

In this specification the equality of the real interest rate is not assumed. Here as the price level is realized at the end of the time period and interest rate difference create incentives for the future decisions hence these variables effect the Nominal Exchange Rate after one Lag.

Converting equation (16) into stochastic form to get

$\mathrm{S}_{\mathrm{t}}=\alpha_{50}+\beta_{51} \mathrm{P}_{\mathrm{t}-1}-\beta_{52} \mathrm{P}_{\mathrm{t}-1} *+\beta_{53} \mathrm{i}_{\mathrm{t}-1}-\beta_{54} \mathrm{i}_{\mathrm{t}-1} *+\gamma_{\mathrm{t}}---(17)$

Now this final stochastic equation (17) will be used for the estimation of the exchange rate patterns using the relevant variables that are used and described above.

The effect of all the variables to the Exchange Rate seem reasonable by the fact that the lag is very small and as domestic and foreign people see the prices and interest rate of foreign and domestic countries at the end of the time period respectively so they respond in the next time period.

\section{Hypotheses}

Picking up from already defined general objectives, the empirical and theoretical foundation refines it to become specific hypotheses for this paper which are as follows;

H1. Is this CHEERS model reasonable to explain the exchange rate deviations in Long Run?

H2. Does PPP and UIP holds individually for the case of Pakistan while CHEERS explains the exchange rate patterns?

H3. Is the Actual Exchange Rate aligned with the proposed Equilibrium pattern suggested by the CHEERS Model?

H4. Does the CHEERS Model have sufficient forecasting power?

These above stated hypotheses will be tested one after the other in the estimation chapter in order to achieve some level of information that can help in forming policy implications for the future.

\section{Data Analysis}

In this section, the variables that are going to be used for the paper are checked for their empirical patterns. 


\subsection{Exchange Rate}

Exchange Rate being primary focus of the study, describing the amount of Pakistani Rupees required to trade 1 US Dollar. This Monthly time series indicator from 1991M3 to 2010M5, taken from IFS CD 2010. The time graph represented in figure 1 shows that there is a continuous devaluation of Pakistani Rupee throughout the time except the duration of early 2000 to mid 2007, where there was inflow of Dollars in form of donations for being ally in war of terror.

Table 1. Exchange rate of Pakistan

\begin{tabular}{|l|l|l|l|l|}
\hline Years & Average & Variance & $\begin{array}{l}\text { Variance } \\
\text { Coefficient }\end{array}$ & $\begin{array}{l}\text { Average } \\
\text { growth }\end{array}$ \\
\hline $91 \mathrm{~m} 3-96 \mathrm{~m} 2$ & 28.35 & 10.76 & 0.37 & 0.19 \\
\hline $96 \mathrm{~m} 3-01 \mathrm{~m} 2$ & 46.01 & 45.42 & 0.98 & 0.44 \\
\hline $01 \mathrm{~m} 3-06 \mathrm{~m} 2$ & 59.43 & 3.03 & 0.05 & -0.02 \\
\hline $06 \mathrm{~m} 2-10 \mathrm{~m} 5$ & 70.38 & 107.93 & 1.53 & 0.50 \\
\hline Source: IFS 2010 \\
\hline
\end{tabular}

\subsection{Price Level of Pakistan}

Price level of Pakistan is generated from Consumer Price Index (CPI) comprising of duration from 1991M3 to 2010M5, taken from International Financial Statistics. The 5 yearly breakup of the historical pattern of price level of Pakistan in table 2 showed that it has been increasing thorough out with high volatility at first and last periods, representing higher degree of Inflation confirmed from the figure 4. Highest Inflation in the last period was caused by the food shortage in the country. This pattern of the price level suggests that with this increasing price level the foreign products are becoming relatively cheaper all the time.

Table 2. Price level of Pakistan

\begin{tabular}{|l|l|l|l|l|}
\hline Years & Mean & Variance & $\begin{array}{l}\text { Variance } \\
\text { Coefficient }\end{array}$ & $\begin{array}{l}\text { Percentage } \\
\text { Change }\end{array}$ \\
\hline $91 \mathrm{~m} 3-96 \mathrm{~m} 2$ & 45.29 & 49.90 & 1.10 & 0.39 \\
\hline $96 \mathrm{~m} 3-01 \mathrm{~m} 2$ & 41.10 & 35.62 & 0.50 & 0.34 \\
\hline $01 \mathrm{~m} 3-06 \mathrm{~m} 2$ & 88.87 & 59.73 & 0.67 & 0.41 \\
\hline $06 \mathrm{~m} 2-10 \mathrm{~m} 5$ & 135.82 & 545.87 & 4.01 & 1.42 \\
\hline \multicolumn{5}{|l|}{ Source: IFS 2010 } \\
\hline
\end{tabular}




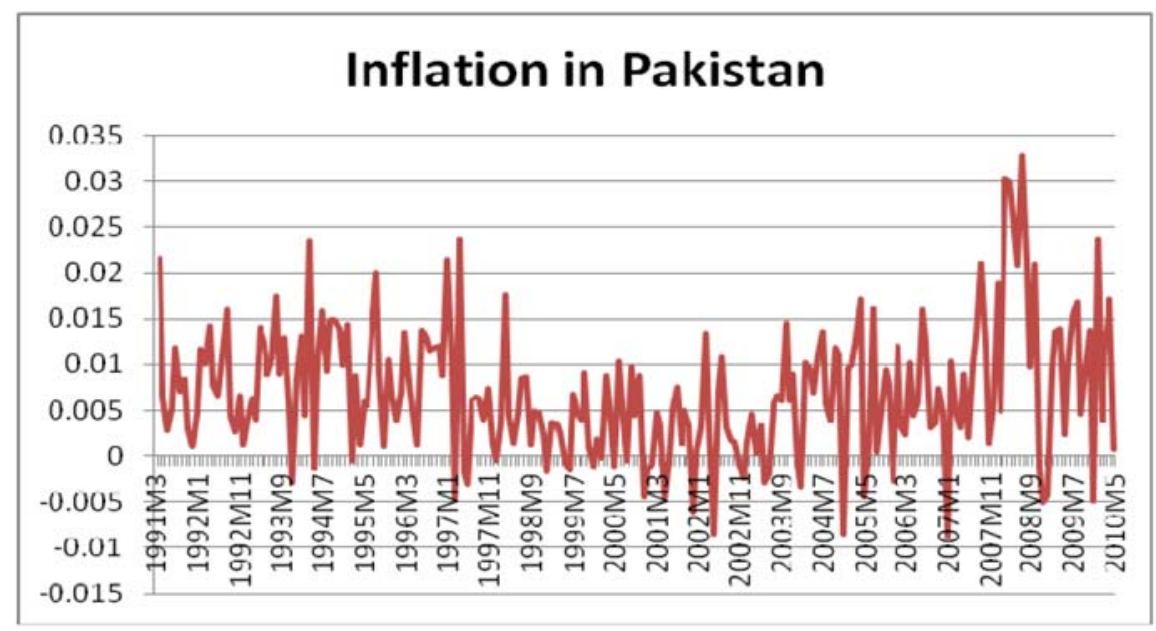

Figure 3. Change in price level of Pakistan (inflation)

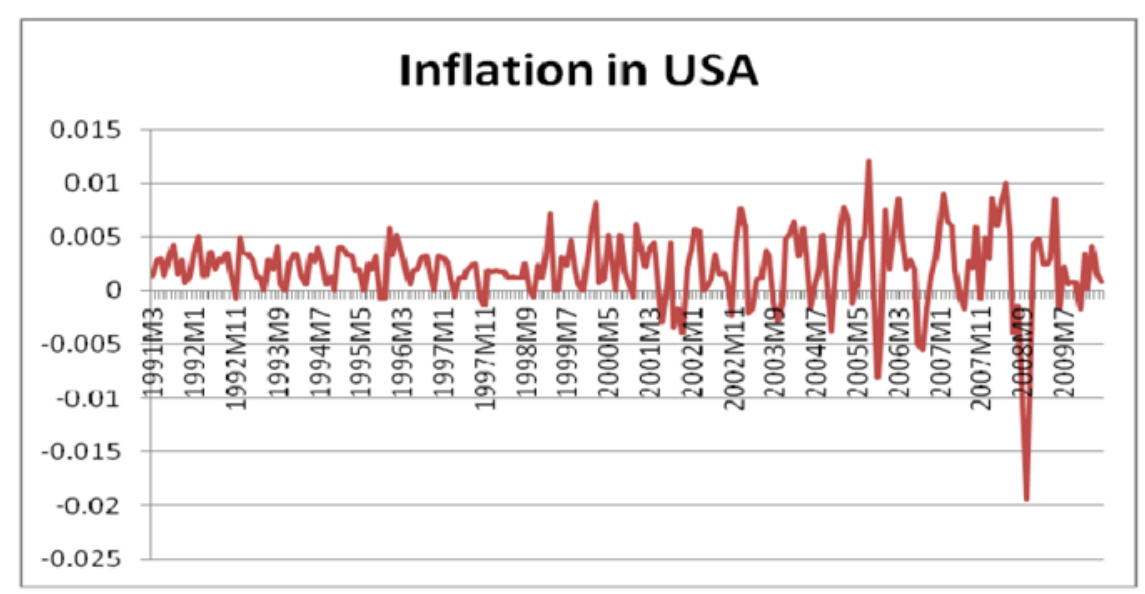

Figure 4. Change in price level of USA (inflation)

\subsection{Price Level of USA}

The 5 year break up description of Price level of USA for the time period of 1991M3 to 2010M5 is taken from International financial statistics, reveal that it started higher level as Pakistan's price level but its increase is slower and more stable that's why there is initial decrease then increase in the price differential figure 2. Because of stable policies, Price level of USA has a significant lower level of volatility suggesting that there is a lower level of inflation too, as seen in the figure 5. 


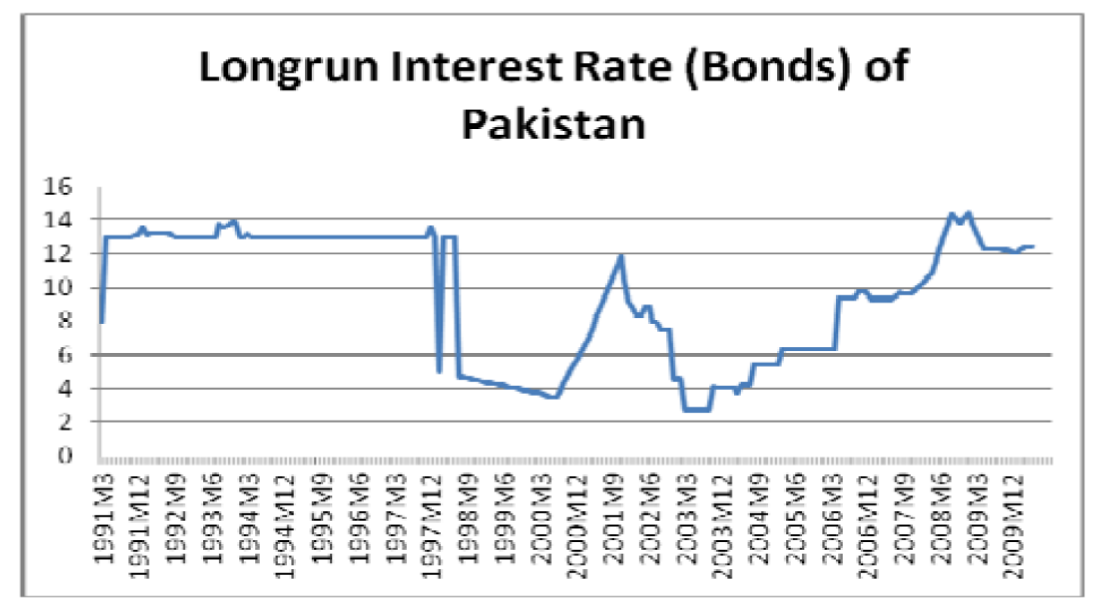

Figure 5. Long run interest rate (bonds)

As Pakistan's price level is increasing faster than the USA price level, hence the gap between the prices is widening and making the USA market more reachable as seen in figure 2. Hence an arbitrage opportunity is created where consumers can buy cheaper goods from abroad as compared to home.

Table 3. Price level of USA

\begin{tabular}{|l|l|l|l|l|}
\hline Years & Mean & Variance & $\begin{array}{l}\text { Variance } \\
\text { Coefficient }\end{array}$ & $\begin{array}{l}\text { Percentage } \\
\text { Change }\end{array}$ \\
\hline $91 \mathrm{~m} 3-96 \mathrm{~m} 2$ & 74.23 & 9.01 & 0.12 & 0.002 \\
\hline $96 \mathrm{~m} 3-01 \mathrm{~m} 2$ & 84.24 & 8.08 & 0.09 & 0.002 \\
\hline $01 \mathrm{~m} 3-06 \mathrm{~m} 2$ & 95.13 & 12.58 & 0.13 & 0.002 \\
\hline $06 \mathrm{~m} 2-10 \mathrm{~m} 5$ & 107.99 & 9.23 & 0.08 & 0.001 \\
\hline Source: IFS 2010 & \multicolumn{5}{|l}{} \\
\hline
\end{tabular}

\subsection{Long term Interest Rate of Pakistan}

In order to see the financial sector effect on the change of exchange rate, Bond rate of Pakistan is used as long run interest rates. This time series data comprises of duration from 1991M3 to 2010m5, taken from International financial statistics 2010. Looking at the graph, the financial market was constant up till the mid 1990's where the combination of international and national events plummeted the local financial market. The higher sensitivity of the interest rates from year 2000 onwards against the economic events is due to the efforts of Shaukat Aziz and his

Team in development of the banking and the financial sector. 


\section{Macrothink}

Table 4. Long term interest rate (bonds) of Pakistan

\begin{tabular}{|l|l|l|l|l|}
\hline Years & Mean & Variance & $\begin{array}{l}\text { Variance } \\
\text { Coefficient }\end{array}$ & $\begin{array}{l}\text { Percentage } \\
\text { Change }\end{array}$ \\
\hline $91 \mathrm{~m} 3-96 \mathrm{~m} 2$ & 13.01 & 0.49 & 0.03 & 0.01 \\
\hline $96 \mathrm{~m} 3-01 \mathrm{~m} 2$ & 8.28 & 18.99 & 2.29 & -0.04 \\
\hline $01 \mathrm{~m} 3-06 \mathrm{~m} 2$ & 6.23 & 5.45 & 0.87 & -0.01 \\
\hline $06 \mathrm{~m} 2-10 \mathrm{~m} 5$ & 11.09 & 3.83 & 0.34 & 0.01 \\
\hline Source: IFS 2010 \\
\hline
\end{tabular}

\subsection{Long term Interest Rate of USA}

Bond Rate is used as Long run interest rate of USA for the time period 1991M3 to 2010M5 taken from international financial statistics shows a somewhat cyclical downward trend, where it showed high degree of stability and a small amount of variability around the mean throughout.

Comparing the interest rate differential of Pakistan and USA there is an increasing trend and this gets prominent from early 2000's. Hence with the increase in the gap, the rate of currency exchange that is required to keep the marginal value of investment constant in Pakistani Rupee faces an upward pressure, which is also confirmed by the increasing Exchange Rate.

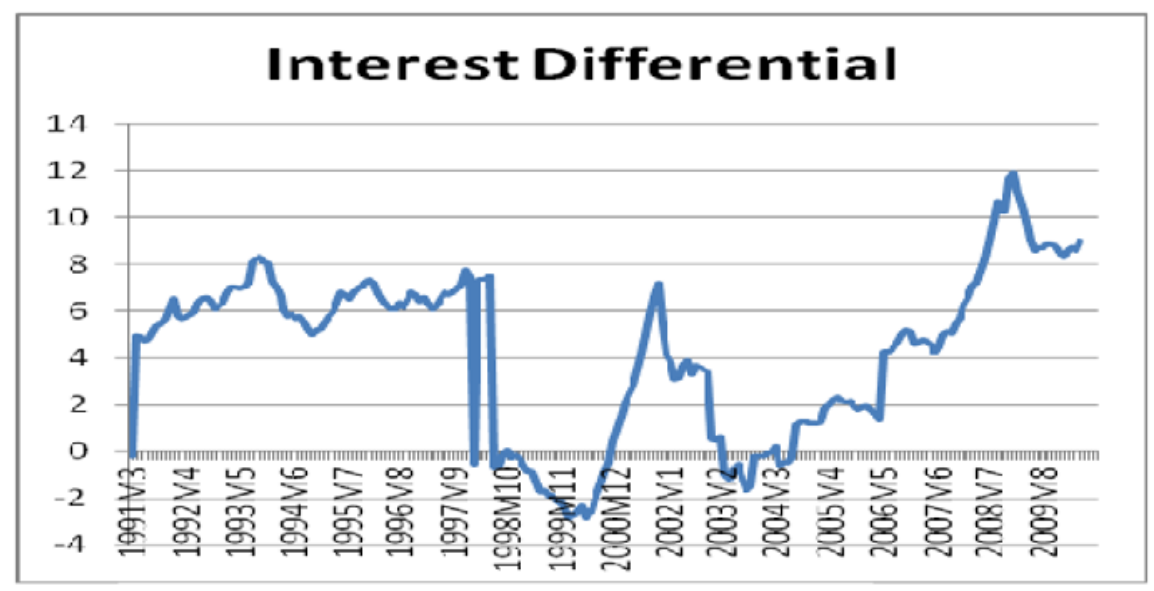

Figure 6. Interest differential 


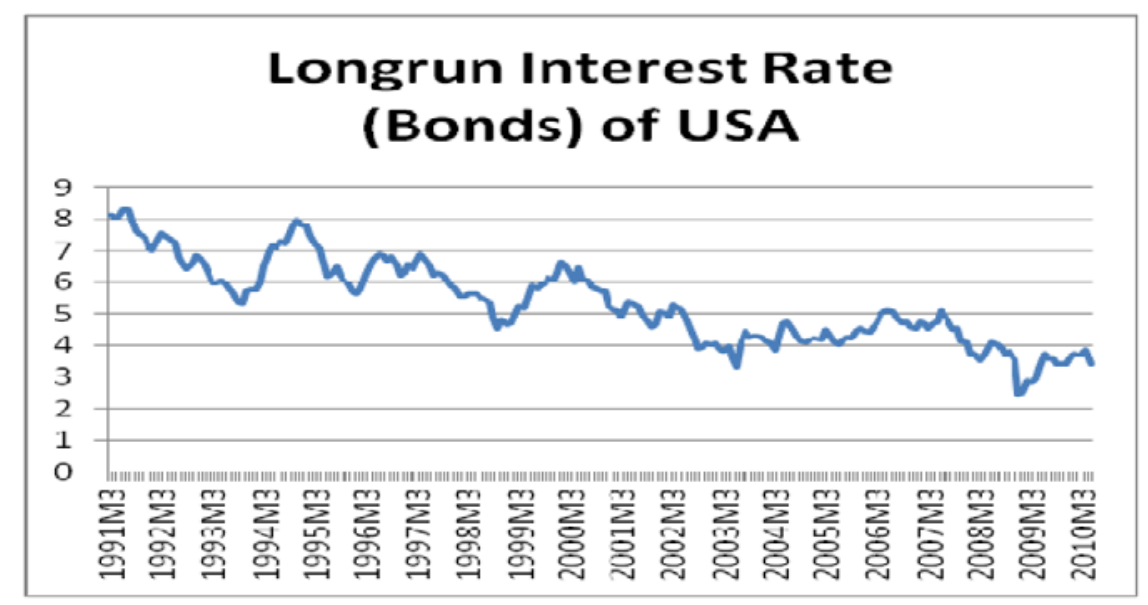

Figure 7. Long run interest rate

Table 5. Long term interest rate (bonds) of USA

\begin{tabular}{|l|l|l|l|l|}
\hline Years & Mean & Variance & $\begin{array}{l}\text { Variance } \\
\text { Coefficient }\end{array}$ & $\begin{array}{l}\text { Percentage } \\
\text { Change }\end{array}$ \\
\hline $91 \mathrm{~m} 3-96 \mathrm{~m} 2$ & 6.80 & 0.67 & 0.1 & -0.01 \\
\hline $96 \mathrm{~m} 3-01 \mathrm{~m} 2$ & 5.92 & 0.38 & 0.06 & -0.004 \\
\hline $01 \mathrm{~m} 3-06 \mathrm{~m} 2$ & 4.42 & 0.211 & 0.04 & -0.002 \\
\hline $06 \mathrm{~m} 2-10 \mathrm{~m} 5$ & 4.03 & 0.51 & 0.13 & -0.03 \\
\hline IFS 2010 \\
\hline
\end{tabular}

\subsection{Relationship of Exchange Rate with PPP and UIP}

Comparing the association between the Exchange Rate and PPP revealed that deviation of the Price Differential between both counties around its mean is around $91 \%$ similar to the deviation of Exchange Rate around its mean. This Pearson correlation coefficient is significant at $1 \%$ (table 6). Looking at the graph for the comparison of the movement of change in Exchange Rate and Price Differential, there is very high similarity between their movements in late 2000's, where it can be thought that they both are more interactive with each other.

In comparison of the Exchange Rate and UIP, the Pearson correlation analysis shows that the increase in the bond rate of Pakistan positively associated with change the Exchange Rate and increase in the bond rate of USA negatively change the exchange rate. And from figure 3 it can be seen that the peaks of this Interest rate Differential is matched by high change in the Exchange Rate. Now in the next chapter, the estimation will be done using these variables. 
Table 6. Correlation analysis of exchange rate using PPP

\begin{tabular}{|l|l|l|l|l|}
\hline \multicolumn{2}{|l|}{} & $\begin{array}{l}\text { Price } \\
\text { Level of } \\
\text { Pakistan }\end{array}$ & $\begin{array}{l}\text { Price } \\
\text { Level of } \\
\text { USA }\end{array}$ & $\begin{array}{l}\text { Price } \\
\text { Differential }\end{array}$ \\
\hline \multirow{2}{*}{$\begin{array}{l}\text { Exchange Rate of } \\
\text { Pakistan }\end{array}$} & $\begin{array}{l}\text { Pearson } \\
\text { Correlation }\end{array}$ & $0.942^{*}$ & $0.944^{*}$ & $0.908^{*}$ \\
\cline { 2 - 5 } & $\begin{array}{l}\text { Significance } \\
\text { (2-tailed) }\end{array}$ & 0.000 & 0.000 & 0.000 \\
\hline *correlation significant at 1\% level \\
\hline Self calculated using Spss 16
\end{tabular}

Table 7. Correlation analysis of exchange rate using UIP

\begin{tabular}{|l|l|l|l|}
\hline \multicolumn{2}{|c|}{} & $\begin{array}{l}\text { Bond } \\
\text { Rate of } \\
\text { Pakistan }\end{array}$ & $\begin{array}{l}\text { Bond } \\
\text { Rate of } \\
\text { USA }\end{array}$ \\
\hline \multirow{5}{*}{ Change in the Exchange Rate } & $\begin{array}{l}\text { Pearson } \\
\text { Correlation }\end{array}$ & 0.085 & -.0 .033 \\
\cline { 2 - 4 } & $\begin{array}{l}\text { Significance } \\
(\mathbf{2} \text {-tailed) }\end{array}$ & 0.197 & 0.615 \\
\hline Self calculated using Spss 16 & & \\
\hline
\end{tabular}

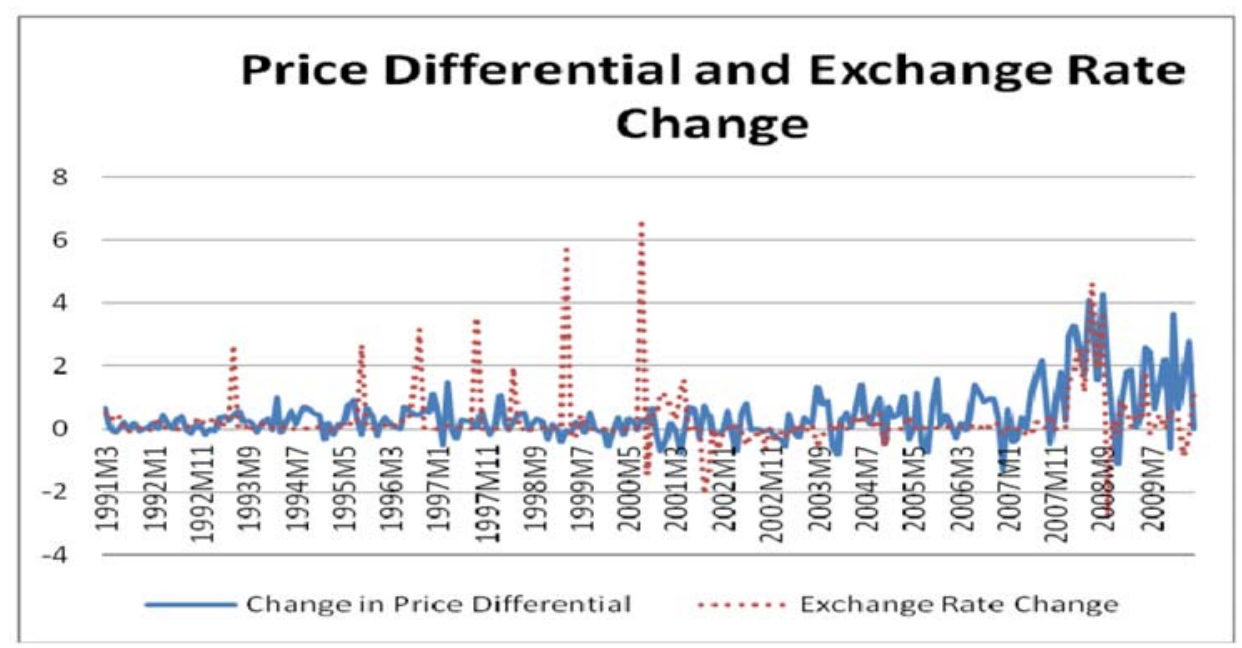

Figure 8. Price differential and exchange rate change

\subsection{Estimation}

This section will take the preliminary analysis of relationship among variables discussed above and use it in the estimation platform. For the estimation process all the series must 
have similar order, higher the order more complex the method required to estimate the long run parameters. So following are the stationary tests that will check the order of the series.

\subsubsection{Stationary Tests}

\subsubsection{Augmented Dickey Fuller Test (ADF)}

This test builds on the prevous results and is based on a theory that if the stronger the ability of the past to explain present, closer will be the mean of the series to infinity, which will be statistically and emperically non-meaningful for the variables thats are discussed.

Consider the specificaiton form:

$$
\mathrm{X}_{\mathrm{t}}=\alpha \mathrm{X}_{\mathrm{t}-1}+\mathrm{t}^{---}(18)
$$

Higher the ability of the past more the $\alpha \rightarrow|1|$, and more the value of $X_{t} \rightarrow \infty$. This property is called Unit Root.

$\Delta \mathrm{X}_{\mathrm{t}}=(\alpha-1) \mathrm{X}_{\mathrm{t}-1}+\mathrm{t}^{---}(19)$

(Dickey \& Fuller, 1979) used this modification to the above unit root test so that it will be more dynamic and robust.

$\Delta \mathrm{X}_{\mathrm{t}}=\alpha_{0}+\beta \mathrm{X}_{\mathrm{t}-1}+\lambda \mathrm{t}+\quad \mathrm{t}---(20)$

Where $\beta=(\alpha-1)$

There is a problem that $\Delta \mathrm{X}_{\mathrm{t}}=\mathrm{f}\left(\Delta \mathrm{X}_{\mathrm{t}-\mathrm{i}}\right)$, which can make $\mathrm{t}_{\mathrm{t}}=\mathrm{g}(\mathrm{t}-\mathrm{i})$ where $\mathrm{i}=1,2, \ldots, \mathrm{n}$ so transformation is done in equation (20) to break up this relationship in the residuals the augmented form is created.

$\Delta \mathrm{X}_{\mathrm{t}}=\alpha_{0}+\beta \mathrm{X}_{\mathrm{t}-1}+\lambda \mathrm{t}+\Sigma \Omega_{\mathrm{i}} \Delta \mathrm{X}_{\mathrm{t}-1-\mathrm{i}}+\mathrm{t}^{---}(21)$

$\mathbf{H}_{\mathbf{0}} ; \beta=0$ (non-stationary series $\mathrm{I}(1)$ and $\left.\alpha=1\right) \quad \mathbf{H}_{\mathbf{1}} ; \beta \neq 0$ (stationary series, $\mathrm{I}(0)$ and $\alpha \neq 1$ )

This hypothesis on $\beta$ does not have standard T-distribution, so this parameter is checked against special critical values that depend upon the number of dynamics, data length and specifications like trend and intercept.

The Augmented Dickey Fuller test represented that for all the variables except Bond Rate of USA, test statistic shows the acceptance of the null hypothesis concluding that these series are non-stationary in nature and are integrated to order I(1). There is no hint of presence of trend in these series too. For the case of the Bond Rate of USA it showed hint of stationarity at only $10 \%$ level, but using 5\% level ad benchmark and the significant trend, the Bond Rate of USA can be considered as non-stationary. These variables are tested in another class of test, these set of tests are used to form the robust form of results. 
Table 8. Augmented dickey fuller test

\begin{tabular}{|l|l|l|l|l|l|l|}
\hline Series & Intercept & $\begin{array}{l}\text { Lag level } \\
\text { Parameter }\end{array}$ & $\begin{array}{l}\text { Time } \\
\text { parameter }\end{array}$ & $\begin{array}{l}\text { No of } \\
\text { Dynamics }\end{array}$ & $\begin{array}{l}\text { Test } \\
\text { Statistic }\end{array}$ & P-Value \\
\hline Exchange rate & $0.06^{*}$ & -0.016 & 0.0001 & 0 & -1.474 & 0.838 \\
\hline $\begin{array}{l}\text { Price level of } \\
\text { Pakistan }\end{array}$ & 0.03 & -0.007 & 0.000 & 3 & -1.109 & 0.927 \\
\hline $\begin{array}{l}\text { Price level of } \\
\text { USA }\end{array}$ & 0.15 & -0.036 & 0.000 & 2 & -1.587 & 0.797 \\
\hline $\begin{array}{l}\text { Bond Rate of } \\
\text { Pakistan }\end{array}$ & 0.06 & -0.028 & 0.000 & 1 & -1.286 & 0.891 \\
\hline $\begin{array}{l}\text { Bond Rate of } \\
\text { USA }\end{array}$ & $0.17 * *$ & $-0.088 * *$ & $-0.0002 * *$ & 2 & -3.278 & $0.070 *$ \\
\hline *significant at 10\% $* *$ significant at 1\% & \\
\hline
\end{tabular}

\subsubsection{Phillips Peron test}

(Phillips \& Peron, 1988) builds on the Augmented Dickey Fuller Test by using non-parametric corrected test statistic to correct for the unspecified autocorrelation and hetroscedasticity. The results of Philips Peron Test are following;

Table 9. Phillips Peron test

\begin{tabular}{|l|l|l|l|l|l|l|l|}
\hline Series & Intercept & $\begin{array}{l}\text { Lag level } \\
\text { Parameter }\end{array}$ & $\begin{array}{l}\text { Time } \\
\text { parameter }\end{array}$ & $\begin{array}{l}\text { Newey-west } \\
\text { Lags }\end{array}$ & $\begin{array}{l}\text { Test } \\
\text { Statistic } \\
\mathbf{z}(\mathbf{t})\end{array}$ & $\begin{array}{l}\text { Test } \\
\text { Statistic } \\
\mathbf{z}(\mathbf{r h o})\end{array}$ & $\begin{array}{l}\text { P-Value } \\
\text { for z(t) }\end{array}$ \\
\hline $\begin{array}{l}\text { Exchange } \\
\text { rate }\end{array}$ & $0.06 *$ & $0.98 * * *$ & 0.000 & 4 & -1.600 & -4.332 & 0.838 \\
\hline $\begin{array}{l}\text { Price level } \\
\text { of Pakistan }\end{array}$ & 0.02 & $-0.99 * * *$ & 0.000 & 4 & -1.000 & -2.226 & 0.944 \\
\hline $\begin{array}{l}\text { Price level } \\
\text { of USA }\end{array}$ & 0.13 & $0.97 * * *$ & 0.000 & 4 & -1.722 & -9.159 & 0.741 \\
\hline $\begin{array}{l}\text { Bond Rate } \\
\text { of Pakistan }\end{array}$ & $0.11 *$ & $0.95 * * *$ & -0.000 & 4 & -1.704 & -7.273 & 0.749 \\
\hline $\begin{array}{l}\text { Bond Rate } \\
\text { of USA }\end{array}$ & $0.14 * * *$ & $-0.92 * * *$ & - & 4 & $-3.318^{*}$ & $-21.475 * *$ & $0.063 *$ \\
\hline *significant at $\mathbf{1 0} \% * *$ \\
\hline
\end{tabular}

The results of this Philips Peron test show that using the 5\% criteria, all the variables that are going to be used, have non-stationary behavior, which confirms the results of previous test. 


\section{Al Macrothink}

Business and Management Horizons

ISSN 2326-0297

2013, Vol. 1, No. 1

Here again like Augmented Dickey Fuller test the Bond Rate of USA is a border line case, sorting this out, needs a robust method that is independent of this issue. As all the variables found are non-stationary with order of integration 1 i.e. I(1) and Bond Rate of USA being a border line case, Ordinary Least Square Method (OLS) to estimate causality will not be appropriate, so another method is used that estimates long run perimeters and short run dynamics and suitable for I(1) variables called Co-integration and Error Correction Model.

\subsubsection{Co-integration Long Run Estimates}

The Co-integration equation is estimated in the following, representing the long run (level) parameters;

Table 10. Long run estimate equation

\begin{tabular}{|c|c|c|c|c|c|}
\hline \multicolumn{6}{|c|}{ Engle-Granger $1^{\text {st }}$-step regression } \\
\hline \multirow{2}{*}{ Dependent variable } & \multirow{2}{*}{ Intercept } & \multicolumn{4}{|l|}{ Parameters } \\
\hline & & $\mathrm{P}_{\mathrm{t}-1}$ & $\mathrm{P}_{\mathrm{t}-1}^{*}$ & $i_{\mathrm{t}-1}$ & $\mathrm{i}_{\mathrm{t}-1}{ }^{*}$ \\
\hline St & 3.11 & $1.03(0.09)$ & $-0.73(0.27)$ & $-0.10(0.103)$ & $--.13(0.051)$ \\
\hline \multicolumn{6}{|c|}{ Standard Errors in Parenthesis. All parameters significant at $1.4 \%$} \\
\hline \multicolumn{6}{|c|}{ Engle-Granger test regression } \\
\hline \multirow{2}{*}{ Dependent Variable } & Parameter & Test statistic & \multicolumn{3}{|c|}{ Critical Values } \\
\hline & 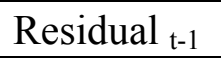 & $\mathrm{Z}(\mathrm{t})$ & $1 \%$ & $5 \%$ & $10 \%$ \\
\hline$\Delta$ Residuals & $-0.04(0.02)$ & -2.25 & -4.73 & -4.15 & -3.85 \\
\hline
\end{tabular}

The Univariate Co-integration test suggests that even though the variables are significantly affecting the exchange rate, still there is no evidence for the presence of co-integration even at $10 \%$ level hence there is no long run equilibrium relationship between these variables. The problem of non existing equilibrium and Bond Rate of Pakistan having wrong expected signs may due to of two reasons, one is the presence of boundary line I(1) variable that could be considered $\mathrm{I}(0)$ and another case might be the issue of endogeniety as in long run all variables may affect with each other.

As this linear combination of the variables (i.e. residuals), are found to be non-stationary hence an Error Correction Model cannot be constructed to see the short run deviations around this long run path The gap between the Actual and the Estimated Exchange Rate that this Long Run Estimate Equation predicts move together seen in figure 10, accept for the year 2001 and 2002 where the model is suggesting the Actual Exchange Rate to be Overvalued, but this results are expected to be misleading and spurious because of the lack of converging ability of this linear combination. 


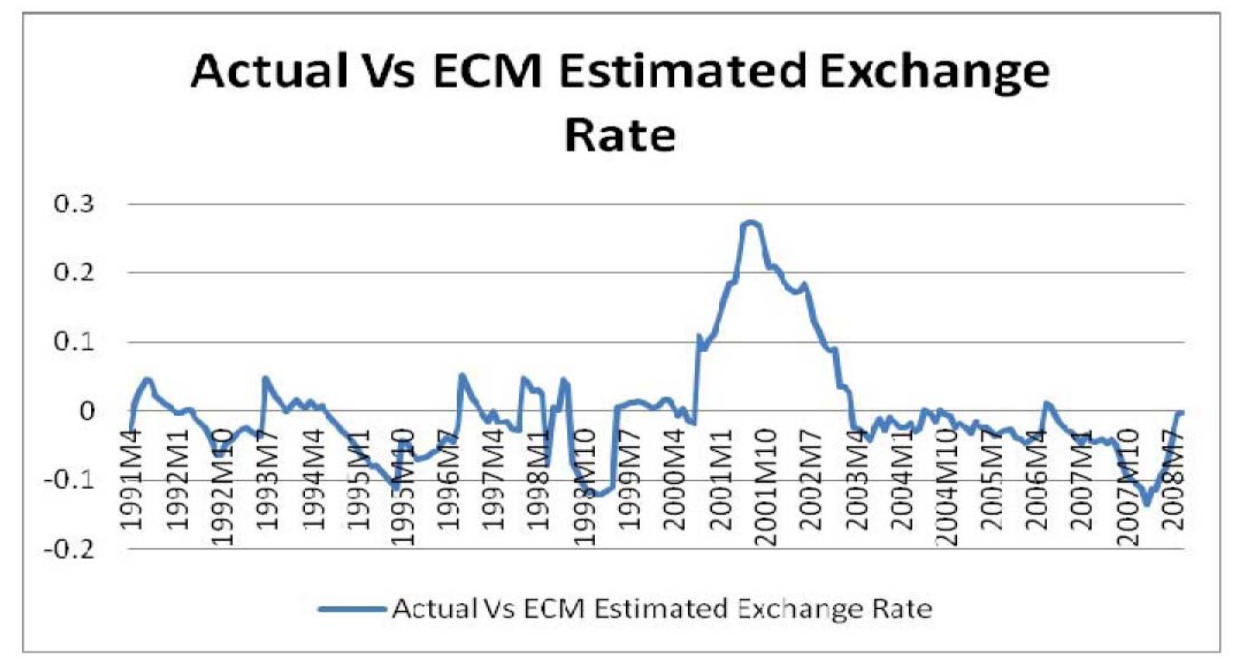

Figure 9. Actual vs ECM estimated exchange rate

\subsection{Multivariate Analysis}

For the multivariate analysis following vector is used

$\mathrm{x}=\left[\mathrm{S}, \mathrm{P}, \mathrm{P}^{*}, \mathrm{i}, \mathrm{i}^{*}\right]$

In this vector form the long run equilibrium can be written at minimum of $\mathrm{k}$ number of ways, and all the valid equilibriums will be statistically different from each other that cannot be transformed into one form or the other. So out of five possible equilibriums, rank method will be applied to find the number of significant equilibriums. The rank test checked using several lag structures, the hypothesis revealed that there in one linear combination among all these variables this will show properties of convergence and hence called as long run equilibrium path. Now a Vector Error Correction Model will be estimated below with given specification of lags that washed away the autocorrelation among residuals and the rank (Long Run Equation) suggested by the Trace test. 
Table 11. Vector error correction model

\begin{tabular}{|c|c|c|c|c|c|c|c|c|c|c|}
\hline & Short $\mathrm{R}$ & Paramet & & & & & Long $\mathbf{R}$ & n Parame & & \\
\hline Series & $\begin{array}{l}\Delta \\
\operatorname{Ln}(S)_{t-1}\end{array}$ & $\begin{array}{l}\Delta \\
\operatorname{Ln}(\mathrm{P})_{\mathrm{t}-2}\end{array}$ & $\begin{array}{l}\Delta \\
\operatorname{Ln}\left(\mathrm{P}^{*}\right)_{\mathrm{t}-2}\end{array}$ & $\Delta \operatorname{Ln}\left(\mathrm{i}_{\mathrm{t}-2}\right.$ & $\begin{array}{l}\Delta \\
\operatorname{Ln}\left(\mathrm{i}^{*}\right)_{\mathrm{t}-2}\end{array}$ & $\mathrm{EC}_{\mathrm{t}-1}$ & $\operatorname{Ln}(\mathrm{P})_{\mathrm{t}-1}$ & $\operatorname{Ln}\left(\mathrm{P}^{*}\right)_{\mathrm{t}-1}$ & $\operatorname{Ln}(\mathrm{i})_{\mathrm{t}-1}$ & $\operatorname{Ln}\left(i^{*}\right)_{t-1}$ \\
\hline$\Delta \operatorname{Ln}(S)_{t}$ & $\begin{array}{l}0.016 \\
(0.071)\end{array}$ & $\begin{array}{l}0.413 \\
(0.203)\end{array}$ & $\begin{array}{l}0.780 \\
(0.527)\end{array}$ & $\begin{array}{l}0.007 \\
(0.009)\end{array}$ & $\begin{array}{l}0.051 \\
(0.031)\end{array}$ & $\begin{array}{l}-0.022 \\
(0.008)\end{array}$ & \multirow{5}{*}{\begin{tabular}{|l|}
2.72 \\
$(0.461)$
\end{tabular}} & \multirow{5}{*}{$\begin{array}{l}-6.87 \\
(1.364)\end{array}$} & \multirow{5}{*}{$\begin{array}{l}0.074 \\
(0.071)\end{array}$} & \multirow{5}{*}{$\begin{array}{l}-1.33 \\
(0.258)\end{array}$} \\
\hline $\begin{array}{l}\Delta \\
\operatorname{Ln}(\mathrm{P})_{\mathrm{t}-1}\end{array}$ & $\begin{array}{l}0.016 \\
(0.025)\end{array}$ & $\begin{array}{l}0.219 \\
(0.071)\end{array}$ & $\begin{array}{l}0.324 \\
(0.185)\end{array}$ & $\begin{array}{l}-0.004 \\
(0.003)\end{array}$ & $\begin{array}{l}0.016 \\
(0.011)\end{array}$ & $\begin{array}{l}-0.0003 \\
(0.003)\end{array}$ & & & & \\
\hline $\begin{array}{l}\Delta \\
\operatorname{Ln}\left(\mathrm{P}^{*}\right)_{\mathrm{t}-1}\end{array}$ & $\begin{array}{l}0.011 \\
(0.010)\end{array}$ & $\begin{array}{l}-0.046 \\
(0.029)\end{array}$ & $\begin{array}{l}0.493 \\
(0.075)\end{array}$ & $\begin{array}{l}-0.0001 \\
(0.001)\end{array}$ & $\begin{array}{l}0.010 \\
(0.004)\end{array}$ & $\begin{array}{l}-0.0001 \\
(0.001)\end{array}$ & & & & \\
\hline$\Delta \operatorname{Ln}(\mathrm{i})_{\mathrm{t}-1}$ & $\begin{array}{l}0.412 \\
(0.532)\end{array}$ & $\begin{array}{l}2.269 \\
(1.518)\end{array}$ & $\begin{array}{l}0.029 \\
(3.940)\end{array}$ & $\begin{array}{l}-0.249 \\
(0.072)\end{array}$ & $\begin{array}{l}0.117 \\
(0.233)\end{array}$ & $\begin{array}{l}0.169 \\
(0.063)\end{array}$ & & & & \\
\hline $\begin{array}{l}\Delta \\
\operatorname{Ln}\left(i^{*}\right)_{t-1}\end{array}$ & $\begin{array}{l}-0.014 \\
(0.159)\end{array}$ & $\begin{array}{l}-0.137 \\
(0.454)\end{array}$ & $\begin{array}{l}3.633 \\
(1.179)\end{array}$ & $\begin{array}{l}0.015 \\
(0.021)\end{array}$ & $\begin{array}{l}0.302 \\
(0.069)\end{array}$ & $\begin{array}{l}-0.076 \\
(0.019)\end{array}$ & & & & \\
\hline
\end{tabular}

These results are produced that makes $\left[\mathrm{S}, \mathrm{P}, \mathrm{P}^{*}, \mathrm{i}, \mathrm{i}^{*}\right] \sim \mathrm{I}(0)$ and calculates any deviations from this long run path through the response given by following $\left[\Delta \mathrm{S}, \Delta \mathrm{P}, \Delta \mathrm{P}^{*}, \Delta \mathrm{i}, \Delta \mathrm{i}^{*}\right]$ vector of variables in short run.

A valid vector error correction model (confirmed by Lagrange Multiplier test on residuals) results revealed, the domestic prices and interest rate affect the exchange rate positively in long run and the foreign prices and interest rate affect the future exchange rate negatively. Hence this hints the presence of PPP and UIP in long run equilibrium.

$\mathrm{S}_{\mathrm{t}}=-25.1+2.72 \mathrm{P}_{\mathrm{t}-1}-6.87 \mathrm{P}_{\mathrm{t}-1} *+0.073 \mathrm{i}_{\mathrm{t}-1}-1.33 \mathrm{i}_{\mathrm{t}-1} *+\gamma_{\mathrm{t}}---$

As the variables used in the model are in logarithmic form so the parameters estimated will be representing the elasticities of that particular independent variable with respect to the nominal Exchange Rate (dependent variable). Analyzing the long run relationship reveals a $1 \%$ increase in the domestic prices of Pakistan increase the Exchange rate in next time period by $2.72 \%$ on average; this more than one percent respond can be due to the ease with which the consumer can shift between local and foreign goods and services due to trade.

A $1 \%$ increase in the foreign (USA) prices will significantly decrease the exchange rate by $6.8 \%$ on average; this highly elastic response is mainly due to of some reasons like USA being a large economy and any change in the price level of USA effects the price level of the world, secondly Pakistan had pegged his Rupee with USA Dollar in the past and thirdly the amount of trade between USA and Pakistan is large enough that change in prices can alter consumers buying decisions and hence effect the exchange rate. As both domestic and foreign prices affect the exchange rate significantly, so the Purchasing Power Parity holds in long run for the case of Pakistan.

A $1 \%$ increase in the long term bond rate of Pakistan will increase the exchange rate of 


\section{Macrothink}

Pakistan by only $0.07 \%$ on average; this effect is very inelastic and statistically insignificant too. Its slight positive effect might be only due to the recent development of this industry that made bond rate more fluctuating to changes in the economy.

And a $1 \%$ increase in the long term bond rate of USA will significantly decrease the exchange rate of Pakistan by $1.33 \%$ on average: hence changes in the financial outlook of USA affect the Pakistan economy by the Exchange rate.

In any economy, any deviations from the long run path cause short run movement in these economic variables to bring back the equilibrium. A $1 \%$ deviation from the linear equilibrium path causes decrease in change of exchange rate by $0.022 \%$ on average; hence a unit deviation will be recovered in 3 years and 8 months. This slow convergence result comply with (Qayyum, Khan, \& Kair-u-Zaman, 2004). This significant covergence also imply that first Hypothesis is statistically accepted and this CHEERS Model is resonable to explain the Exchange Rate deviations in Long Run.

In short run, the foreign Inflation and Interest rate changes are affecting future change in Exchange Rate significantly. Domestic and Foreign Inflation is effecting the future Domestic Inflation. The foreign Inflation is only caused by past foreign Inflation and Interest Rate change. The domestic interest rate change was only the reason to the future domestic interest rate change and the past foreign Inflation and Interest Rate change is causing the change in foreign Interest Rate.

The VECM stability test in showed that the equilibrium is not stable enough that is why it takes more time than usual to return back to equilibrium after a shock. The LM residual test showed no sign of autocorrelation among the residuals from $1^{\text {st }}$ to $4^{\text {th }}$ order hence the results are considered valid. The normality test showed for some of the variables to be different from the skew-ness of zero and kurtosis to 3 hinting presence of few extreme values present in the data.

\subsection{Testing Parities}

The restrictions will be applied on the Long Run Vector $\left[\mathrm{S}, \mathrm{P}, \mathrm{P}^{*}, \mathrm{i}, \mathrm{i}^{*}\right]$ to see some specific parities with its specifications given in this vector form. 
Table 12. Testing parities

\begin{tabular}{|c|c|c|c|c|c|c|}
\hline Hypothesis & $\mathbf{P}_{\mathrm{t}-1}$ & $\mathbf{P} *_{t-1}$ & $\mathbf{i}_{\mathbf{t}-1}$ & $\mathbf{i}_{\mathrm{t}-1}$ & Chi-Square(v) & P-Value \\
\hline \multirow{2}{*}{1} & \multicolumn{6}{|c|}{$\left[\mathrm{S}, \mathrm{P}, \mathrm{P}^{*}, \mathrm{i}, \mathrm{i}^{*}\right]=[1,1,-1,0,0] \sim \mathrm{I}(0)$} \\
\hline & 1 & -1 & 0 & 0 & $10.07(3)$ & 0.019 \\
\hline \multirow{2}{*}{2} & \multicolumn{6}{|c|}{ Uncovered Interest Parity } \\
\hline & 0 & 0 & 1 & -1 & $10.08(3)$ & 0.018 \\
\hline \multirow{2}{*}{3} & \multicolumn{6}{|c|}{ External Economy Effect $\quad[\mathrm{S}, \mathrm{P}, \mathrm{P} *, \mathrm{i}, \mathrm{i} *]=[1,0,-1,0,-1] \sim \mathrm{I}(0)$} \\
\hline & 0 & -1 & 0 & -1 & $14.35(3)$ & 0.002 \\
\hline \multirow{2}{*}{4} & \multicolumn{6}{|c|}{ Internal Economy Effect } \\
\hline & 1 & 0 & 1 & 0 & $9.305(3)$ & 0.025 \\
\hline \multirow{2}{*}{5} & \multicolumn{6}{|c|}{ Strict PPP and Loose UIP } \\
\hline & 1 & -1 & 0.15 & -0.66 & $0.7954(2)$ & 0.672 \\
\hline \multirow{2}{*}{6} & \multicolumn{6}{|c|}{ Strict PPP and UIP (I) $\quad\left[\mathrm{S}, \mathrm{P}, \mathrm{P}^{*}, \mathrm{i}, \mathrm{i}^{*}\right]=[\mathrm{a}, 1,-1,1,-1] \sim \mathrm{I}(0)$} \\
\hline & 1 & -1 & 1 & -1 & $7.466(3)$ & 0.058 \\
\hline \multirow{2}{*}{7} & \multicolumn{6}{|c|}{ Strict PPP and UIP (II) $\quad\left[\mathrm{S}, \mathrm{P}, \mathrm{P}^{*}, \mathrm{i}, \mathrm{i}^{*}\right]=[1, \mathrm{~b},-1,1,-1] \sim \mathrm{I}(0)$} \\
\hline & 1.37 & -1 & 1 & -1 & $6.339(3)$ & 0.096 \\
\hline
\end{tabular}

For $\mathrm{K}$ variables and 1 co-integrating equations, there must me $\mathrm{K}-\mathrm{I}$ eigenvalues real and near to unity, if any other is near to one, it will suggest that either the equilibrium pattern is non-stationary or the equilibriums are lower than the actual. That is the reason why the convergence speed is slow. Stata Documentation. Four restrictions are only used to purify the relationship and testing the significance of the desired outcome. P-Value higher than 0.05 suggests that the restrictions applied is statistically acceptable at 5\%. This is the specification of the restriction applied; the signs of the variables other than Exchange Rate are actually opposite to what it is written here in the restriction. Here it is corrected to show the desired direction. This restriction is theoretically fine until a $>0$. Both hypothesis 6 and 7 are technically same in the later one restriction is applied on the unity of the Exchange Rate instead of the Domestic Price Level, the results are same the Parameter of the Domestic Price Level is still statistically near to unity but this improved the results.

(MacDonald \& Taylor, 1991) and (Juselius \& MacDonald, 2004) used series of test restrictions to see the validity of the restrictions and to see it the parameters are near to the mathematical model. This paper uses this idea and tests some restrictions for the parities on the long run equilibrium to see if they hold or not.

Statistical evidence using Chi-Square in hypothesis 1 and 2 rejects the presence of PPP and UIP in isolation, this statistically rejects Hypothesis two. The failure of hypothesis 3 and 4 specifies that the nominal Exchange Rate of Pakistan is not controlled by economic activities of only one country; it is the interaction between these two countries that determine the pattern formed by the Exchange Rate.

But on the other hand, the combination of PPP and UIP with different flavors in hypothesis 6 
\& 7 like strict PPP \& loose UIP and Strict PPP and UIP, were statistically acceptable under $5 \%$ criterion. Hence the current equilibrium relationship nests the Strict PPP and Strict UIP in it results similar to conclusion of (Camarero \& Tamarit, 1996) and (Juselius \& MacDonald, 2004) in explaining Exchnage Rate. The acceptance of these restrictions shows that the PPP-UIP model works well inside a sample with almost unit elastic parameters.

Further this PPP-UIP model will be used to estimate the Exchange Rate and compare its pattern with the actual Exchange Rate.

\subsection{Equilibrium Exchange Rate and its Alignment}

The pattern of the Exchange Rate given by the PPP-UIP model, seem more volatile and responsive to the differential of prices and interest rates between Pakistan and USA. The following graph (Figure 10) shows that the Estimated Exchange Rate is mostly present above the Actual Exchange Rate, and if PPP-UIP model is considered a true representative of the Exchange Rate pattern then the shaded gaps in this graph will represent the degree of misalignment of Exchange Rate.

The graph (Figure 11) of the gap between the Actual and Estimated Exchange Rate suggests that there as a little amount of convergence of the Gap to zero point but beyond the year 2000 the gap tend to deviate around the zero point.

Here the increasingly negative gap up till year 2000 means, the Actual Exchange Rate to be below the Estimated Exchange Rate hence suspecting that the Exchange Rate of Pakistan to be increasingly undervalued, due to of increasing domestic price level in Pakistan. These results are similar to (Qayyum, Khan, \& Kair-u-Zaman, 2004) with presistent undervalued Exchange Rate of Pakistan.

After year 2000 this gap seems random around zero, this change may not be surprising when compared what happened around this year in the world. Around year 2000, several events happened like changing of political regime from Democratic to Dictatorship, the 9/11 incident and inclusion of Pakistan as an ally in war against terror.

The Dickey Fuller test of the gap showed that it is not random. Hence the non-stationarity (non-mean-convergence) of this gap statistically proves that the Actual Exchange Rate is not aligned with the Equilibrium Exchange Rate hence rejecting Hypothesis three. 


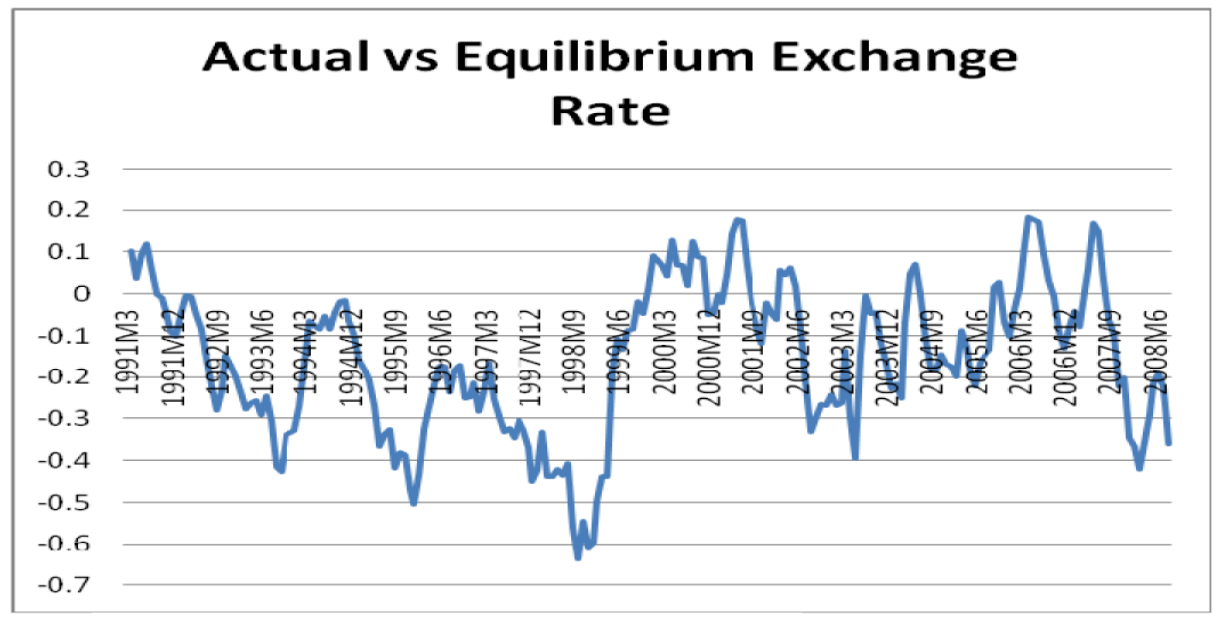

Figure 10. Actual vs Eq. exchange rate

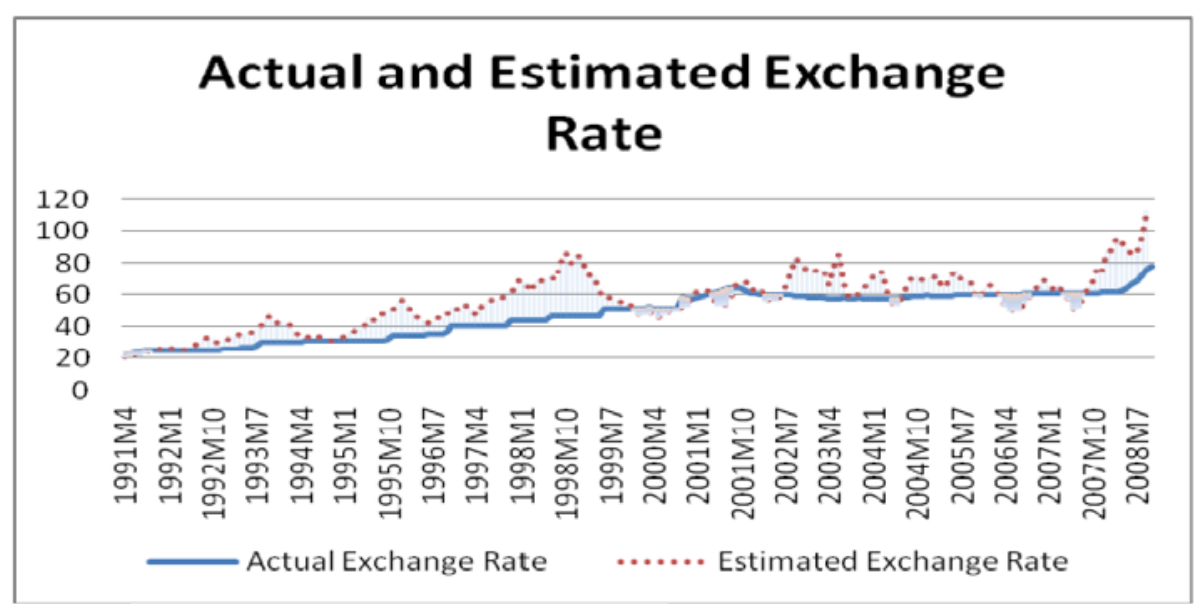

Figure 11. Actual and estimated

\subsection{Forecasting}

As the PPP-UIP model is build now, following test will check to see whether this model can perform well when used for forecasting.

Using PPP-UIP model the forecasting Exchange Rate for next 20 time periods will be done and the comparison ability will be compared with the forecast of Random Walk Model. For this purpose last 20 observations are left out of estimation intentionally. Following two methods will be done to see if the estimated model can perform better than a random walk model in forecasting the exchange rate.

\subsubsection{Root Mean Square Ratio}

In this Root Mean Square is calculated for both models will be calculated as: 


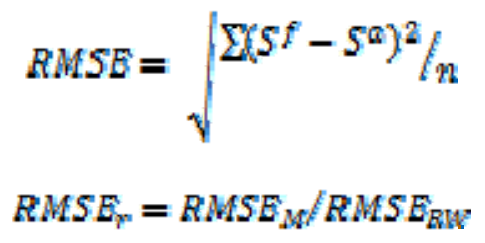

Where

$\mathrm{S}^{\mathrm{f}}=$ Forecasted Exchange Rate, $\quad \mathrm{S}^{\mathrm{a}}=$ Actual Exchange Rate,

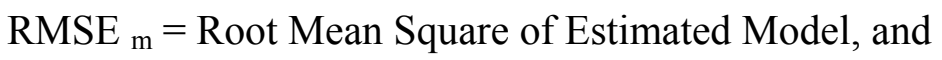

RMSE $_{\mathrm{rw}}=$ Root Mean Square of Random Walk Model

The calculation showed that the RMSE $\mathrm{m}$ and RMSE rw came out to be 0.816 and 0.014 respectively hence the RATIO turns out to be 57, suggesting that the forecasts of the Random Walk Model are more bounded near to the Actual Exchange Rate as compared to the PPP-UIP Model estimate.

But this result might be misleading this case as the PPP-UIP model is already suggesting the presence of misalignment so while forecasting it will still continue the same way, where as the Random Walk is forecasting Exchange Rate in the base of past information available in the Exchange Rate which tends to be near to the actual observations. Hence evaluation of the forecasting ability requires some other method that considers the movement directions important as compared to the actual realization of the Exchange Rate.

\subsubsection{Direction Ability Test}

The previous method by construction was incapable of doing a better forecast that can match the actual Exchange Rate incidence, so a second best method is applied in the following that gives importance to the ability to forecast the direction of the future Exchange Rate.

In this evaluation method, a binary indicator will be created that will have magnitude 1 of the change in the Actual Exchange Rate and Estimated Exchange Rate have same signs otherwise it will have magnitude 0 suggesting that the model has failed to forecast even the direction of the future Exchange Rate.

This procedure will be applied to both of the PPP-UIP and Random Walk Model of the Exchange Rate and then the averages of that indicator will be compared to see which model has higher average, hence higher direction forecasting ability.

The average of the dummy came out to be 0.4 for the PPP-UIP Model Estimated Exchange Rate and 0.5 for the Random Walk Estimated Exchange Rate respectively. This test suggests that the forecasting of the Random Walk is random such that it successfully forecast the direction of the future Exchange Rate by $50 \%$ which is totally random considering that there are only two directions and it should be $50 \%$ by definition too, while in comparison the Model can successfully only forecast the direction of the future Exchange Rate by $40 \%$ hence it is unable to perform better than the Random Walk Model. 
Table 14. Direction ability test

\begin{tabular}{|l|l|l|l|l|l|}
\hline Years & $\begin{array}{l}\text { Model } \\
\text { Direction } \\
\text { Dummy }\end{array}$ & $\begin{array}{l}\text { Random } \\
\text { Walk } \\
\text { Direction } \\
\text { Dummy }\end{array}$ & Years & $\begin{array}{l}\text { Model } \\
\text { Direction } \\
\text { Dummy }\end{array}$ & $\begin{array}{l}\text { Random } \\
\text { Walk } \\
\text { Direction } \\
\text { Dummy }\end{array}$ \\
\hline 2008M10 & 1 & 1 & 2009M8 & 0 & 0 \\
\hline 2008M11 & 0 & 0 & 2009M9 & 1 & 0 \\
\hline 2008M12 & 1 & 0 & 2009M10 & 1 & 1 \\
\hline 2009M1 & 0 & 0 & 2009M11 & 0 & 0 \\
\hline 2009M2 & 0 & 0 & 2009M12 & 1 & 0 \\
\hline 2009M3 & 0 & 1 & $2010 \mathrm{M} 1$ & 0 & 1 \\
\hline 2009M4 & 1 & 1 & $2010 \mathrm{M} 2$ & 1 & 1 \\
\hline 2009M5 & 0 & 1 & $2010 \mathrm{M} 3$ & 0 & 0 \\
\hline 2009M6 & 0 & 1 & $2010 \mathrm{M} 4$ & 1 & 1 \\
\hline 2009M7 & 0 & 1 & $2010 \mathrm{M} 5$ & 0 & 0 \\
\hline Self Calculated & & \\
\hline
\end{tabular}

In the evaluation the Random Walk model performed better than more efficient PPP-UIP model due to of the following expected reasons:

- As the variable Exchange Rate is found out to be non-stationary, so the Random Walk model is able to utilize the higher inertia in the series to forecast the future observations.

- The Misalignment of the Exchange Rate, the scope of the Pakistani Financial Market as compared to the USA Financial Market may have caused the reason for the PPP-UIP model to perform insufficiently outside the sample.

These results suggests, the above defined suitable model does not have good forecasting ability as compared to the Random Walk Model, hence with the given evidence the Hypothesis four is rejected.

\section{Limitations}

The level convergence that is achieved using this model seems not to be very strong so that I can perform better in the forecasting. The equilibrium restores itself in 3 years after a shock so in order to see any performance in the forecasting it should be done for more than 3 years time period (i.e. more than 36 observations) so that it can compete Random Walk Model's forecast.

Secondly this is type of equilibrium model it tells about the situation of the Actual Exchange Rate according to certain conditions so if it is already suggesting the presence of disequilibrium then ultimately it will forecast disequilibrium too so comparing its result to Random Walk Model is irrelevant. 


\section{Contribution \& Policy Implications}

This paper built on the CHEERS model for the Exchange Rate which was not tested for Pakistan economy especially considering that it takes time for the people to respond to price and interest rate opportunities using a lag between dependent and independent variable, while proving that the RMSE method to test forecast is not ideal when there is already disequilibrium, a second best strategy was tried that can check the forecast ability.

Although significant long run relationship is present between the capital and goods market, still the slow convergence shows that these markets might not have independent role in shaping the Exchange Rate of the country. The capital markets should be made stronger as compared to the US market in order to have any power to move or control the Exchange Rate between Pakistan and USA.

The results represented that the Prices in the goods market of Pakistan and USA have highly elastic effect on the change (devaluation/evaluation) of the currency in next time period respectively. Hence in order to avoid further depreciation of the currency, the rising speed of the prices in Pakistan should be slowed down as the Inflation in USA is considerably lower hence it is not sensible to expect that to rise and appreciate Exchange Rate of Pakistan.

\section{Conclusion}

A co-integrated relationship among PPP, UIP and the nominal Exchange Rate of Pakistan/USA found out to be successful in available data range, shows that this PPP and UIP coordinated framework works well as a foundation for any expanded model that can increase the convergence speed of the equilibrium. The results revealed that any increase in the Prices and Interest rate of Pakistan as compared to the Prices and Interest rate of USA translated directly to the increase in the Exchange Rate, hence in response to any arbitrage opportunity the individuals in Goods and Capital market become active to shift their currency in terms of the country where the Good are cheaper or the returns are higher respectively.

The results of rank test and the VECM stability test shows that there was only one equilibrium, which was not very stable and slow converging, suggesting that there is some part of the Exchange Rate pattern that is missing. The non- normality of the variables, also suggested that there might be some non-economic events that altered the course of the relationship.

Several papers corresponding to (Frenkel, J. A. 1976) found that monetary and output differential increases the convergence power of the model, but due the data constraints for the case of Pakistan, this paper only focused on the Performance of CHEERs bases Exchange Rate Model.

The forecasting performance tested against the RW model, may cause misleading results as both set of models include different conditions, it would be better to compare the performance of this CHEERs model with some other similar model 


\section{References}

Ahmad, M. (2005). Purchasing Power Parity based on Capital Account, Exchange Rate Volatility and Cointegration: Evidence from some Developing Countries. Applied Econometrics and International Development, 5(3), 105 - 116.

Baillie, R. T., \& Selover, D. D. (1987). Cointegration and Models of Exchange Rate Determination. International Journal of Forecasting, 43-51. http://dx.doi.org/10.1016/0169-2070(87)90077-X

Camarero, M., \& Tamarit, C. (1996). Cointegration and the PPP and the UIP Hypothesos: An Application to the Spanish Integration in the EC. Open Economies Review, 61-76. http://dx.doi.org/10.1007/BF01886129

Cassel, G. (1918). Abnormal deviations of international exchanges. Economic Journal, 28, 413-415. http://dx.doi.org/10.2307/2223329

Clostermann, J., \& Schnatz, B. (2000). The determinants of the euro-dollar exchange rate; Synthetic fundamentals and a non-existing currency. Discussion Paper 2/00, Economics Research Group of the Deutsche Bundesbank .

Dickey, D. A., \& Fuller, W. A. (1979). Distribution of the Estimatiors for Autoresgrssive Time series With a Unit Root. Journal of the American Statistical Association, 74(366), 427-431. http://dx.doi.org/10.2307/2286348

Enders, W. (1988). ARIMA and Cointegration Tests of PPP under Fixed and Flexible Exchange Rate Regimes. The Review of Economics and Statistics, 70(3), 504 -508. http://dx.doi.org/10.2307/1926789

Enders, W. (2004). Applied Econometric Time Series (3rd ed.). John Wiley \& Sons.

Frenkel, J. A. (1976). A Monetary Approach to the Exchange Rate: Doctrinal Aspects and Emperical Evidence. The Scandinavavian Journal of Economics, 200-224. http://dx.doi.org/10.2307/3439924

Government of Pakistan. (2007-2008). Economic Survey. Islamabad. Economic Adviser's Wing, Ministry of Finance.

Government of Pakistan. (2008-2009). Economic Survey. Islamabad. Economic Adviser's Wing, Ministry of Finance.

Juselius, K., \& MacDonald, R. (2004). International parity relationships between the USA and Japan. Japan and the World Economy, 17-34. http://dx.doi.org/10.1016/S0922-1425(03)00003-3

Kemal, M. A., \& Haider, R. M. (2004). Exchange Rate Behavior after Recent Float: The Experience of Pakistan. The Pakistan Development Review, 43(4), 829-852. 


\section{IIMacrothink}

Business and Management Horizons

ISSN 2326-0297

2013, Vol. 1, No. 1

Khan, M. A., \& Qayyum, A. (2007). Exchange Rate Determination in Pakistan: Evidence based on Purchasing Power Parity Theory. Pakistan Economic and Social Review, 45(2), 181-202.

Lütkepohl, H. (2005). New Introduction to Multiple Time Series Analysis. New York: Springer.

MacDonald, R. (2000). Concepts to Calculate Equilibrium Exchange Rates: An Overview. Discussion paper Economic Research Group of Deutsche Bundesbank .

MacDonald, R., \& Taylor, M. P. (1991). The monetary appriach to the exchange rate; Long-run relationships and coefficients. Economics Letters, 179-185. http://dx.doi.org/10.1016/0165-1765(91)90128-8

Phillips, P. C. B, \& Peron, P. (1988). Testing for a Unit Root in Time Series Regression. Biometrika, 75, 335-346. http://dx.doi.org/10.1093/biomet/75.2.335

Qayyum, A., Khan, A., \& Kair-u-Zaman. (2004). Exchnage Rate Misalignment in Pakistan: Evidence from Purchasing Power Parity Theory. The Pakistan Development Review, 43(4 Part II), 721-735.

\section{Copyright Disclaimer}

Copyright reserved by the author(s).

This article is an open-access article distributed under the terms and conditions of the Creative Commons Attribution license (http://creativecommons.org/licenses/by/3.0/). 